Arkadiusz MACEK ${ }^{1}$

Opiekun naukowy: Maciej ZAWIŚLAK ${ }^{2}$

DOI: https://doi.org/10.53052/9788366249837.16

\title{
ANALIZA WPLYWU AERODYNAMIKI LUSTEREK SAMOCHODU CIĘŻAROWEGO NA ZUŻYCIE PALIWA
}

Streszczenie: Praca przedstawia proces optymalizacji opływu powietrza przez lusterka samochodu ciężarowego oraz wpływ powstałych oporów aerodynamicznych na zużycie paliwa. Kluczową częścią pracy było zaprojektowanie i optymalizacja kształtu lusterek bocznych samochodu ciężarowego, gdyż ich wpływ na opory aerodynamiczne jest znaczący. W pracy przedstawiono wyniki wielu symulacji 3D z zakresu numerycznej mechaniki płynów. Analizowane były kształty lusterek o założonych z góry wymiarach oraz umiejscowieniu, ponieważ zaprojektowane elementy spełniają odpowiednie Europejskie normy z zakresu budowy pojazdów samochodach.

Słowa kluczowe: mechanika płynów, numeryczna mechanika płynów, CFD, samochód ciężarowy, lusterko

\section{THE ANALYSIS OF WING MIRRORS AERODYNAMICS IMPACT ON FUEL CONSUMPTION OF HEAVY DUTY VEHICLE}

Summary: The thesis analyzes the effect of wing mirrors aerodynamics on fuel consumption in heavy-duty vehicle. Essential part of my thesis was designing and optimizing the shape of wing mirrors in heavy-duty vehicle, due to their hefty impact on aerodynamic drag in these types of vehicles. This thesis presents the results of many 3D simulations of computational fluid dynamics. The dimensions and location of the mirrors was predetermined, based on European standards in the construction of heavy-duty vehicles.

Keywords: fluid mechanics, numerical fluid mechanics, CFD, heavy-duty vehicles, mirror

\section{Wprowadzenie}

W ostatnich latach zaobserwowano znaczący trendy $\mathrm{w}$ optymalizacji pracy samochodów ciężarowych. Konstruktorzy starają się poprawić efektywność pracy

1 Politechnika Wrocławska, Wydział Mechaniczny, specjalność: Mechanika i Budowa Maszyn,226850@student.pwr.edu.pl

2 prof. uczelni $\mathrm{dr}$ hab. inż., Politechnika Wrocławska, Wydział Mechaniczny, maciej.zawislak@pwr.edu.pl 
jednostek spalinowych, ergonomii pracy kierowcy oraz poprawę aerodynamiki tych pojazdów. Na drogach poruszają się olbrzymie ilości tych pojazdów, zużywają one znaczące ilości paliwa. Każda nawet najmniejsza poprawa w konstrukcji pojazdu przekłada się na ekologiczną i ekonomiczną poprawę ich eksploatacji.

Jednak pojazdy te muszą spełniać szereg obostrzeń oraz norm. W przypadku lusterek zewnętrznych samochodów ciężarowych norma jaką muszą spełniać te pojazdy na terenie Unii Europejskiej to: „Regulamin nr 46 Europejskiej Komisji Gospodarczej Organizacji Narodów Zjednoczonych (EKG ONZ) - Jednolite wymagania dotyczące homologacji urządzeń widzenia pośredniego oraz homologacji pojazdów silnikowych w odniesieniu do instalacji tych urządzeń"[1]. Norma ta określa ilość oraz położenie lusterek w pojedzie. Każde z lusterek ma określony cel oraz powinno zapewnić odpowiednie pole widzenia do operatora pojazdu.

Z punktu widzenia aerodynamiki pojazdu największą role odgrywają lusterka boczne, są one największe oraz ich położenie powoduje znaczące opory aerodynamiczne pojazdu. $\mathrm{Z}$ tego powodu ich kształt ma znaczący wpływ na poprawę aerodynamiki całego pojazdu oraz na opory jakie powstają w tym pojedzie.

\section{Założenia projektowe}

Podczas procesu analizy wykorzystano następujące założenia:

- masa samochodu ciężarowego, 40000 [kg],

- długość pojazdu, 18,75 [m],

- szerokość pojazdu, 2,55 [m],

- wysokość pojazdu, 3,5 [m],

- prędkość, stała $25[\mathrm{~m} / \mathrm{s}]$,

- podłoże, asfalt,

- brak wzniesienia (ruch po płaskim podłożu),

- spalanie samochodu ciężarowego przed optymalizacją, 351/100km.

Opory ruchu pojazdu zostały wyliczone na podstawie następujących wzorów:

$$
F=F_{t}+F_{p}+F_{w}+F_{b}+F_{u}
$$

$\mathrm{F}_{\mathrm{t}}$ - opory toczenia,

$\mathrm{F}_{\mathrm{p}}$ - opory powietrza,

$\mathrm{F}_{\mathrm{w}}$ - opory wzniesienia,

$\mathrm{F}_{\mathrm{b}}$ - opory bezwładności mas wirujących,

$\mathrm{F}_{\mathrm{u}}$ - opory uciągu.

Opory toczenia:

$$
F_{t}=G f_{t}
$$

$\mathrm{G}$ - ciężar samochodu,

$\mathrm{f}_{\mathrm{t}}$ - współczynnik oporu toczenia,

Opory powietrza:

$$
F_{p}=0,5 \rho c_{d} A V^{2}
$$


$\rho-$ gęstość,

$\mathrm{c}_{\mathrm{d}}$ - współczynnik oporów aerodynamicznych,

A - pole przekroju poprzecznego.

Opory wzniesienia:

$$
F_{w}=G \sin \alpha
$$

$\mathrm{G}$ - ciężar samochodu,

$\alpha$ - kąt wzniesienia.

Opory bezwładności:

$$
F_{b}=\delta G \frac{d v}{d t}
$$

$\delta$ - współczynnik oporów bezwładności mas samochodu, uwzględniający wpływ mas obrotowych,

$\mathrm{G}$ - ciężar samochodu.

Opory uciągu:

$$
F_{u}=F_{t}{ }^{\prime}+F_{p}{ }^{\prime}+F_{w}{ }^{\prime}+F_{b}{ }^{\prime}
$$

\section{Model wykorzystany do analizy CFD}

Do wykonania modeli geometrycznych wykorzystano oprogramowanie AutoCAD Inventor. Natomiast obliczenia CFD wykonano w oprogramowaniu Ansys Fluent 2019 R2. Podczas obliczeń wykorzystano wskazówki zawarte w książce „Metoda projektowania i modernizacji maszyn oraz układów przepływowych z zastosowaniem numerycznej mechaniki płynów”[2]. Model geometryczny wykorzystany do odwzorowania ciągnika siodłowego wraz z naczepą przedstawiono na rysunki 1.

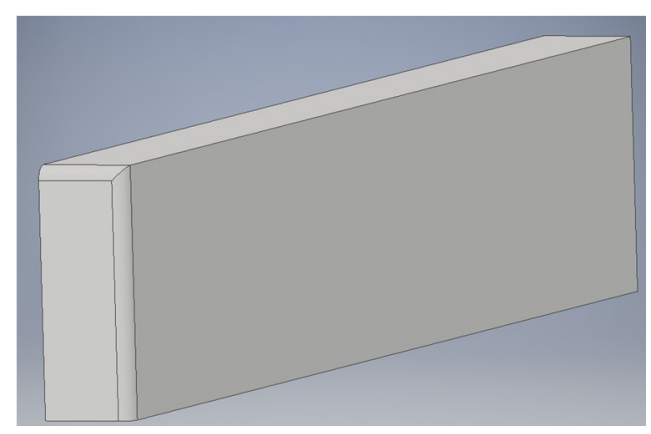

Rysunek 1. Model geometryczny

Model ten został maksymalnie uproszczony oraz wykorzystano symetrię w celu poprawy czasu obliczeń.

Do obliczeń CFD wykorzystano domenę obliczeniową widoczną na rysunku 2. Domena ta posiada wymiary $100 \times 22 \times 22$ [m]. Takie wymiary domeny obliczeniowej 
pozwalają na skuteczny odwzorowanie wszystkich zjawisk aerodynamicznych. Ściany domeny zostały odpowiednio oddalone od geometrii (z zachowaniem ok. jednej długości modelu przed, jednej długości modelu w bok, jednej długości modelu w górę oraz trzech odległości za modelem).

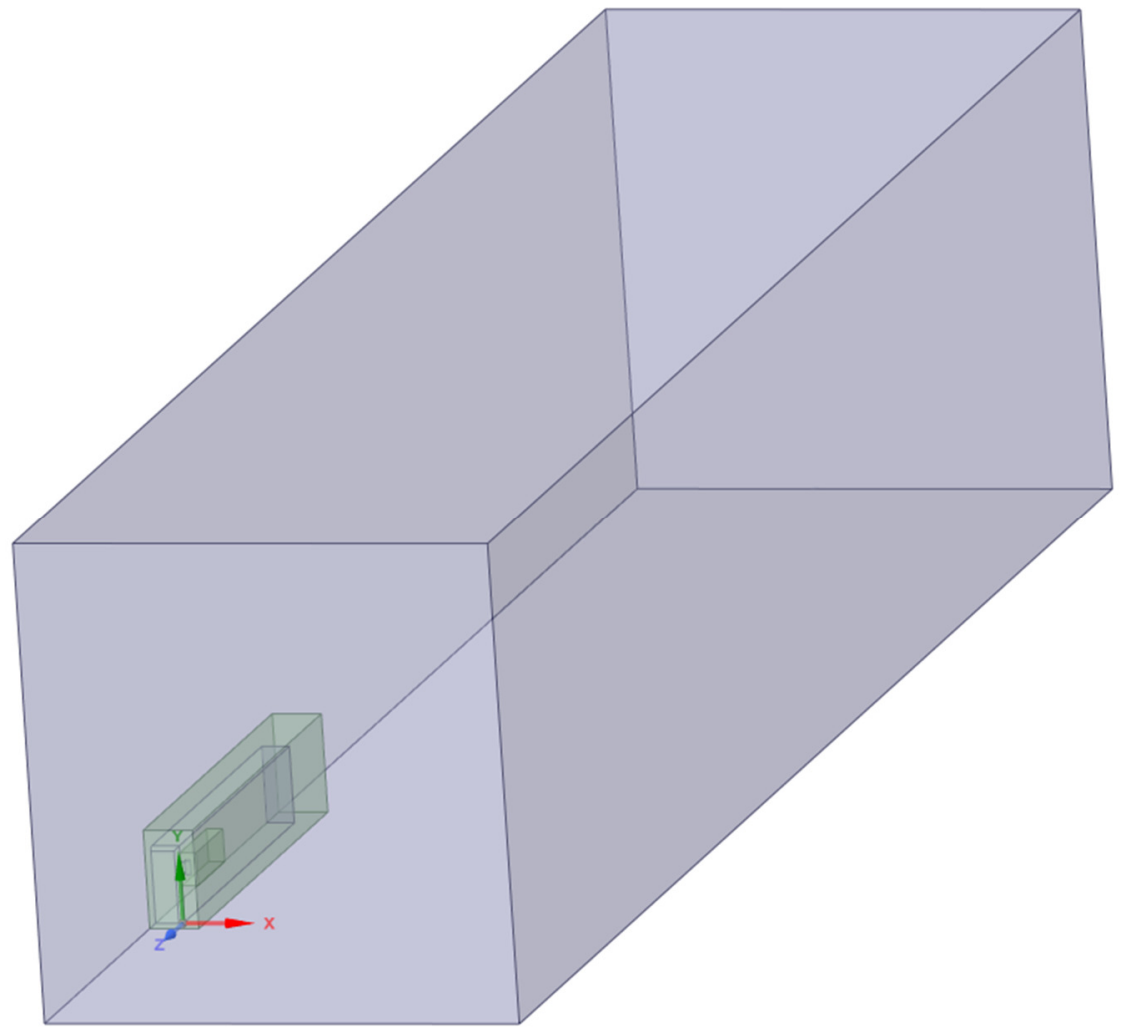

Rysunek 2. Domena obliczeniowa

Model dyskretny składał się z około 7 miliona elementów, wynikało to z braku wystarczająco satysfakcjonującej mocy obliczeniowej. W dyskretyzacji modelu użyte zostały elementy sześcienne. Dla odpowiedniego odwzorowania warstwy przyściennej użyte były dodatkowo elementy typu pryzm (10 warstw, y+ zależny od wielkości elementu). Zastosowane wielkości komórek zostały przedstawione na rysunku 3. Stosowane były także dodatkowe zagęszczenia wolumetryczne, w obszarach występowania największych turbulencji. 

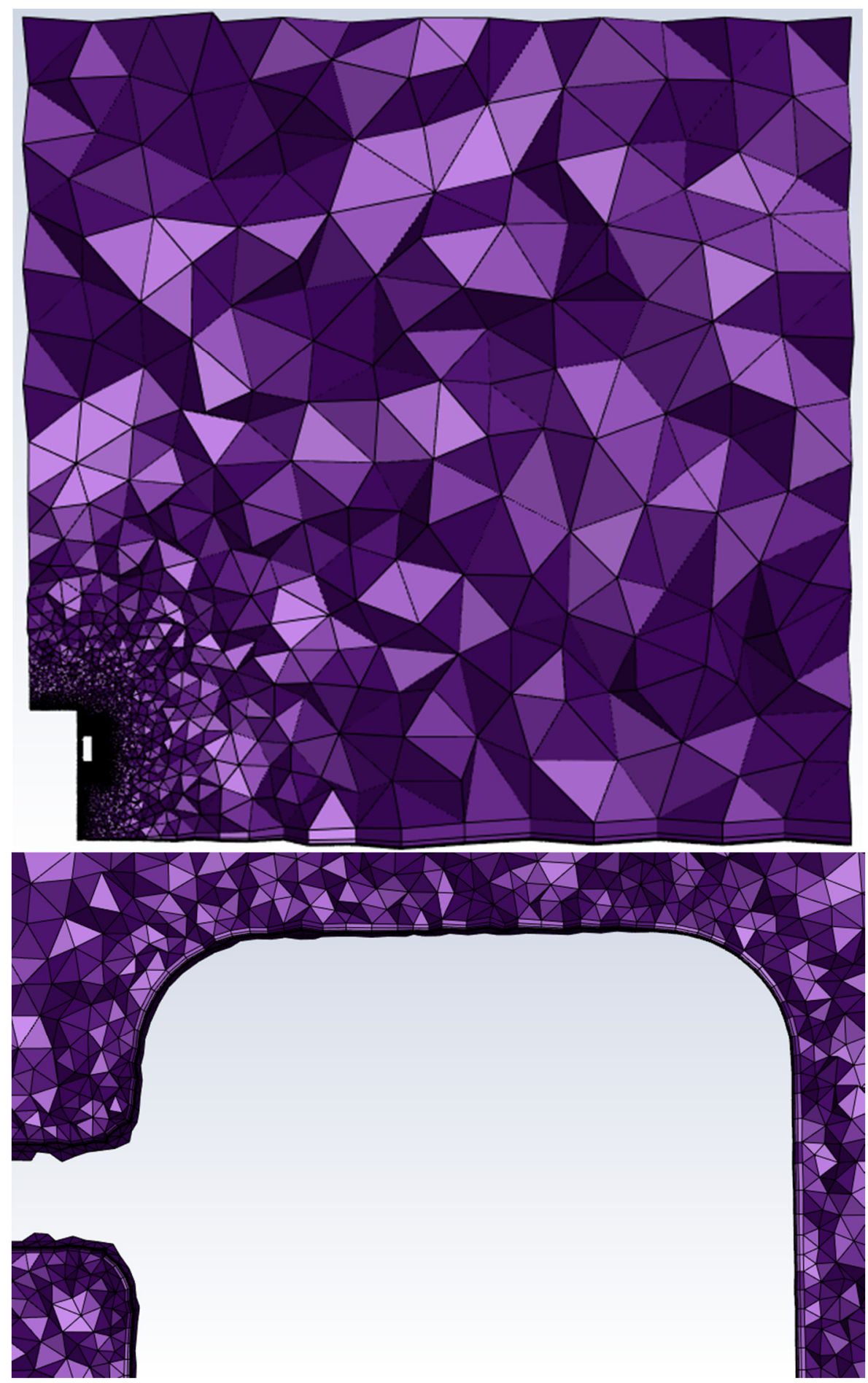

Rysunek 3. Siatka modelu dyskretnego 
Medium jakie zostało wykorzystane podczas analizy to powietrze (air) pochodzące $\mathrm{z}$ bazy danych wbudowanych w oprogramowanie. Wybrano model obliczeniowy k-omega (2 eqn) SST. Warunki brzegowe dostosowano by jak największym stopniu odwzorować rzeczywistość. Powietrze trafiające do domeny porusza się z prędkością $25[\mathrm{~m} / \mathrm{s}]$, czyli 90 [km/h]. Jest to prędkość z jaką poruszają się po drogach publicznych samochody ciężarowe. W celu lepszego odwzorowania ruchu powierzchnia dolna (ground) porusza się w z prędkością $25[\mathrm{~m} / \mathrm{s}]$, odwzorowując poruszające się podłoże. Elementy modelu są odwzorowane dzięki ścianą lepkim, natomiast ściana demony obliczeniowej jest ścianą nie lepką (nie oddziaływa na nią siły lepkości).

\section{Analiza wariantów obliczeniowych}

Do analizy wykorzystano trzy modele lusterek spełniających europejskie nory oraz jeden model kamery.

Model pierwszej symulacji (rysunek 4) przedstawia nieskomplikowaną budowę, lusterka tego typu stosowane był w starszych modelach samochodów ciężarowych. Charakteryzuje się prostokątnymi kształtami o wymiarach 250x450 [mm] oraz 250x240 [mm], mocowaniem zbudowanym z zakrzywionej rury. Wymiary zostały tak dobrane by były spełnione Europejskie normy dotyczące tego elementu.

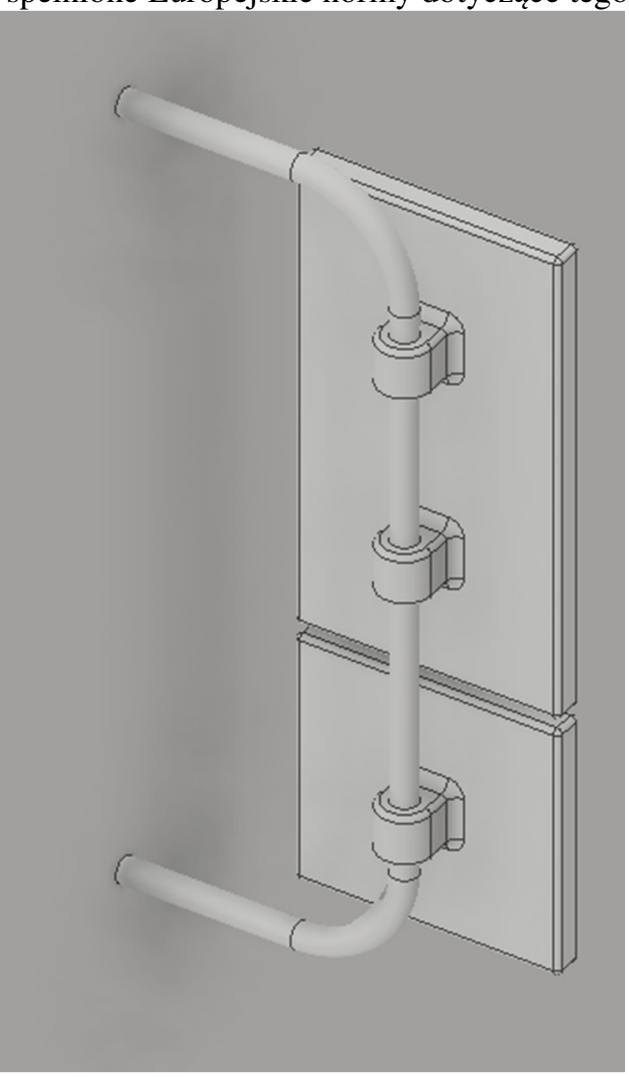

Rysunek 4. Model pierwotnego lusterka 


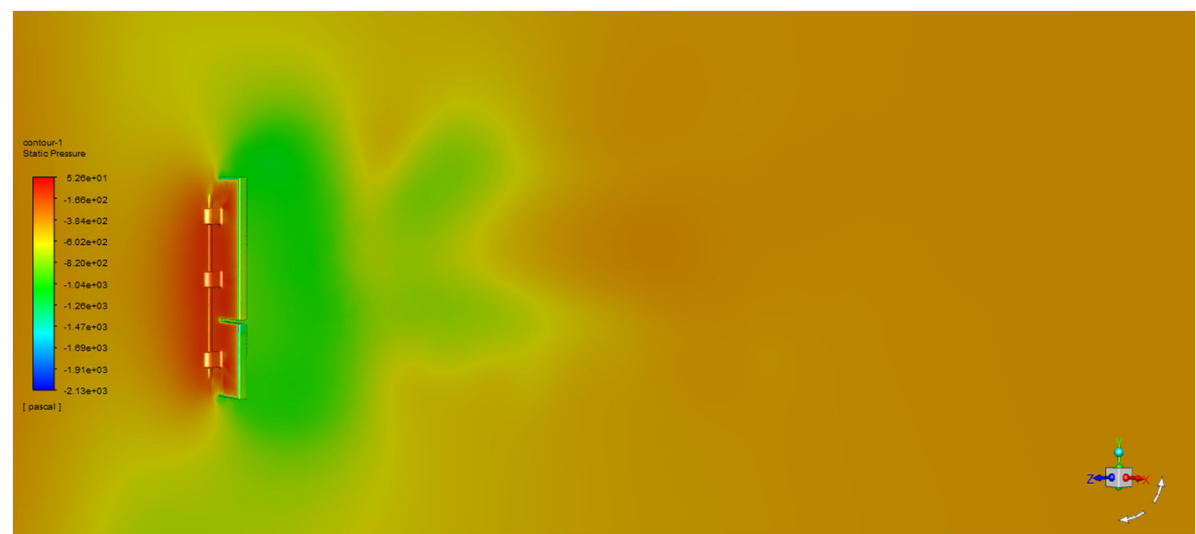

Rysunek 5. Rozkład ciśnień dla pierwszego lusterka

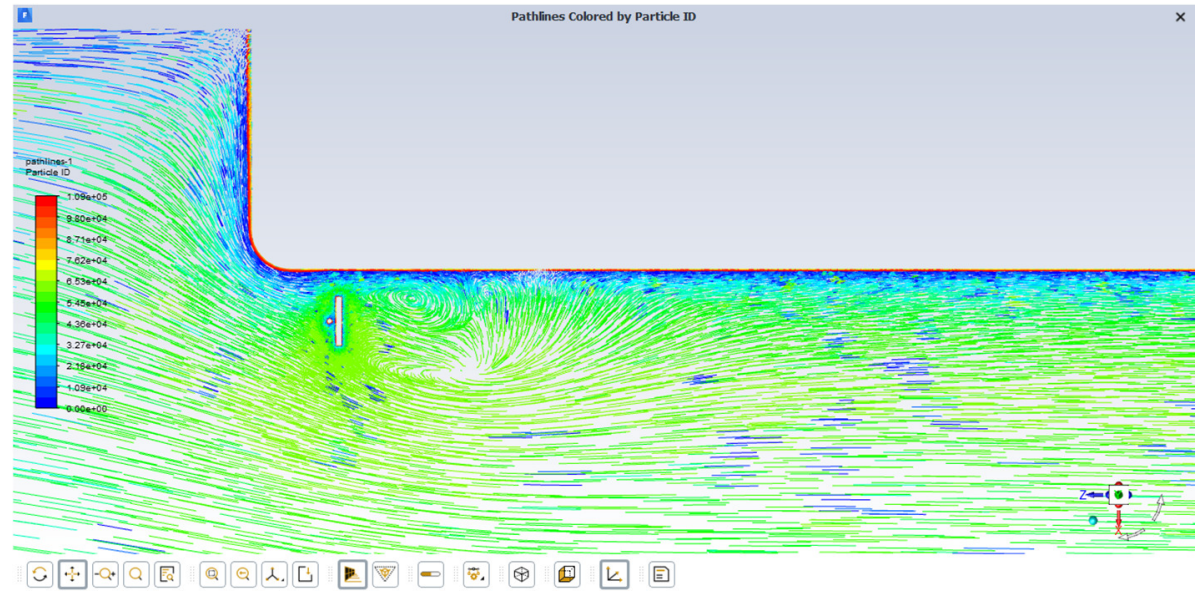

Rysunek 6. Linie przeptywu dla pierwszego lusterka

Tabela 1. Wyniki obliczeń dla pierwszej symulacji

\begin{tabular}{|c|c|}
\hline${\text { Współczynnik } \mathrm{C}_{\mathrm{d}}}$ & Siła oporów [N] \\
\hline 1,63 & 114,9 \\
\hline
\end{tabular}

Model powoduje bardzo duże zawirowania powietrza, oraz dużą separację. Widoczne jest to na rysunku 6. Spadek ciśnienia widoczny na rysunku 5 powoduje znaczne opory aerodynamiczne. Wyniki zostały przedstawione w tabeli 1 .

Kolejny model, po pierwszej optymalizacji kształtu. Charakteryzuje się, zmienionymi kształtami powierzchni czołowej, innym mocowaniem oraz połączeniem dwóch części lusterek w jedną bryłę, widoczne jest to na rysunku 7. Lusterko to w znacznym stopniu polepszyło warunki opływu powietrza, zmniejszył się stopień zawirowań oraz separacji. Wartości oporów znacząco spadły widoczne jest to w tabeli 2. 


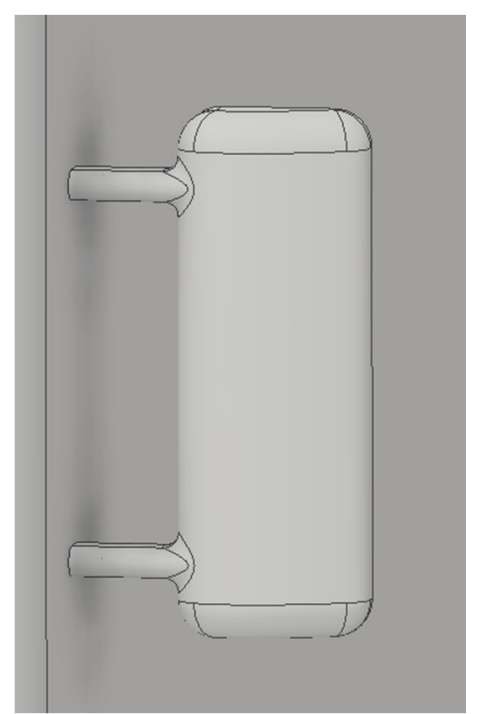

Rysunek 7. Model drugiego lusterka

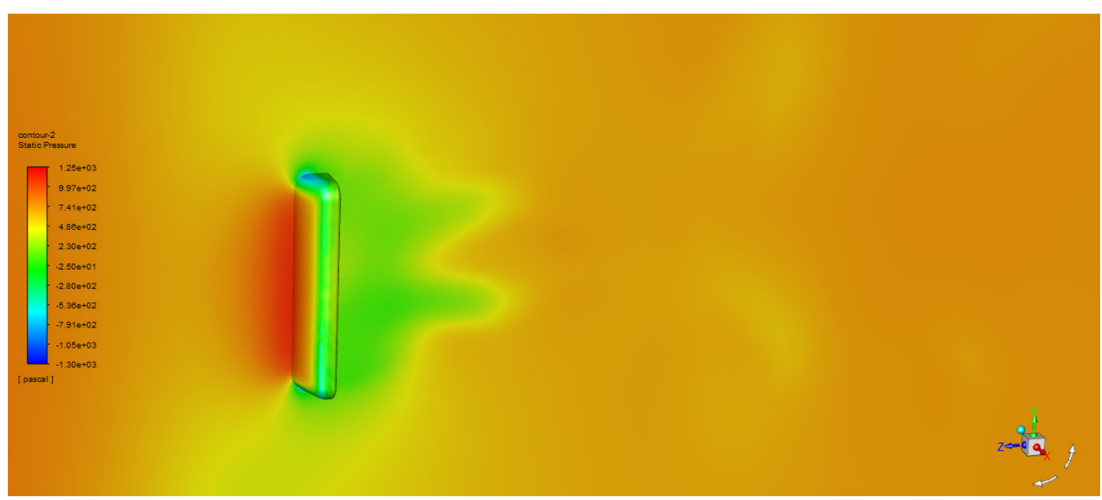

Rysunek 8. Rozkład ciśnień dla drugiego lusterka

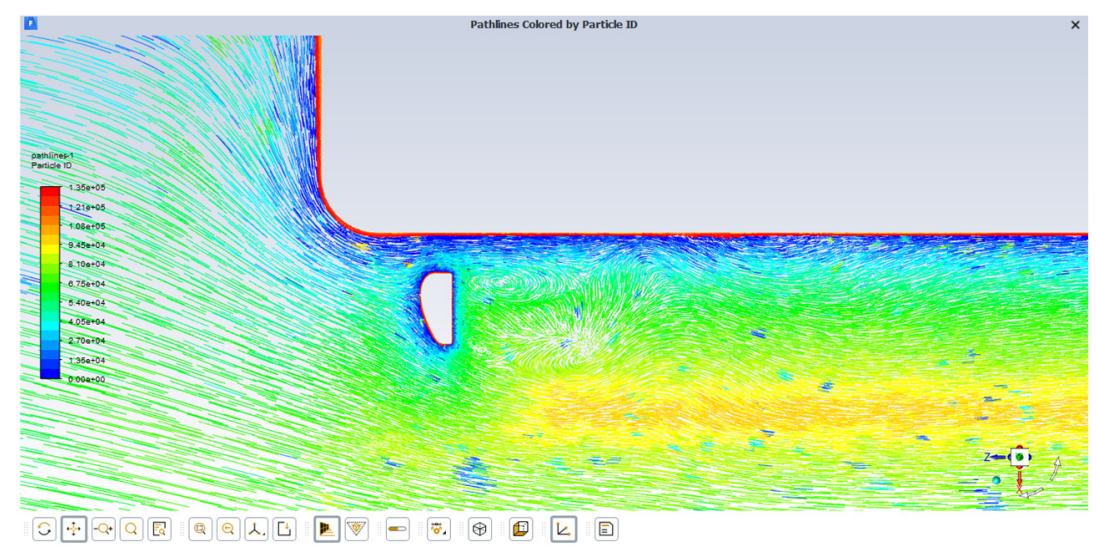

Rysunek 9. Linie przepływu dla drugiego lusterka 
Tabela 2. Wyniki obliczeń dla drugiej symulacji

\begin{tabular}{|c|c|}
\hline Współczynnik $\mathrm{C}_{\mathrm{d}}$ & Siła oporów [N] \\
\hline 0,99 & 72,1 \\
\hline
\end{tabular}

W kolejnym stopniu optymalizacji skupiono się na dalej idącej zmianie kształtu oraz system mocowania lusterka. Wymiary zostawały zastosowane jak w poprzednim modelu, jednak system mocowania został umiejscowiony tylko w dolnej części elementu. Kształt lusterka jest dużo bardziej opływowy (sugerowano się, kształty lusterek w samochodach sportowych). W wyniku modyfikacji osiągnięto dalej idącą poprawę w zmniejszeniu oporów aerodynamicznych.

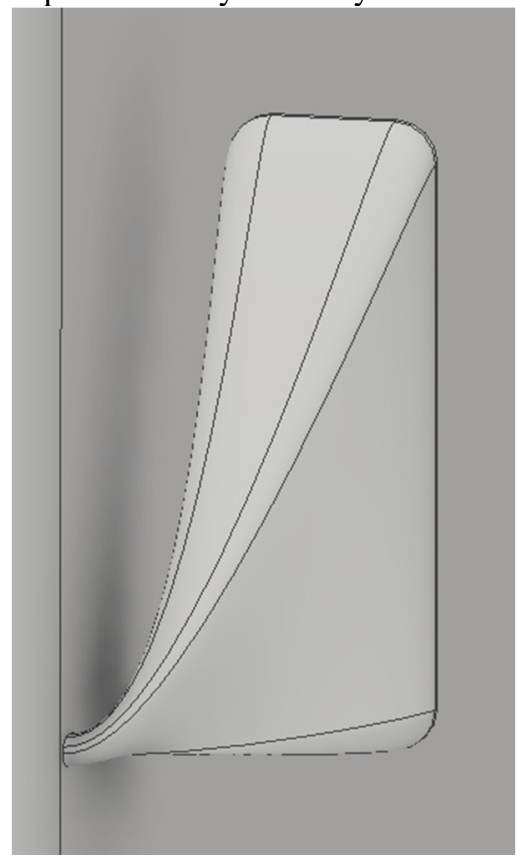

Rysunek 10. Model trzeciego lusterka

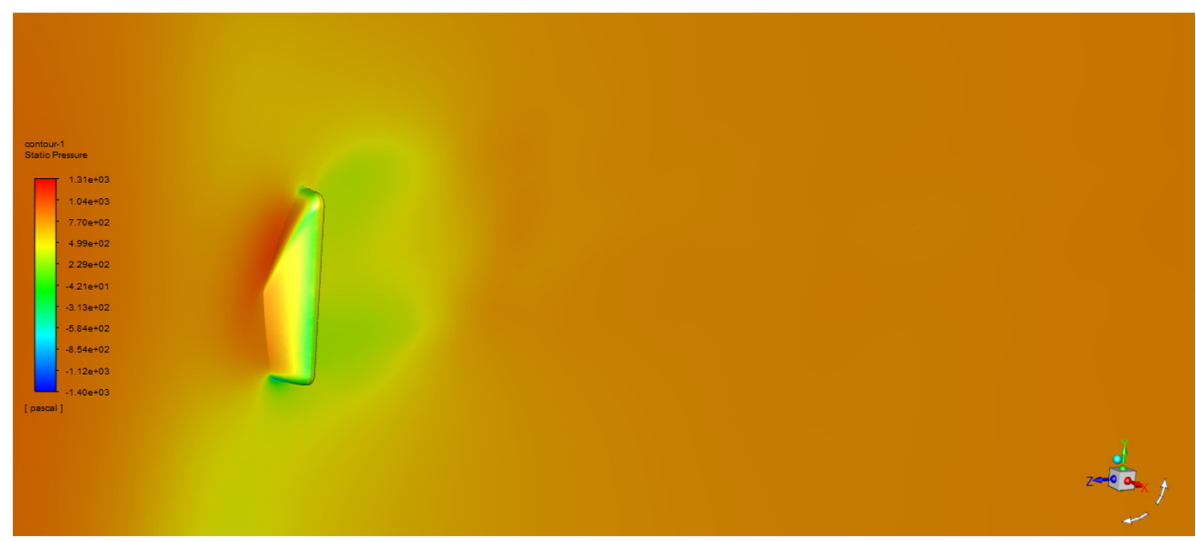

Rysunek 11. Rozkład ciśnień dla trzeciego lusterka 


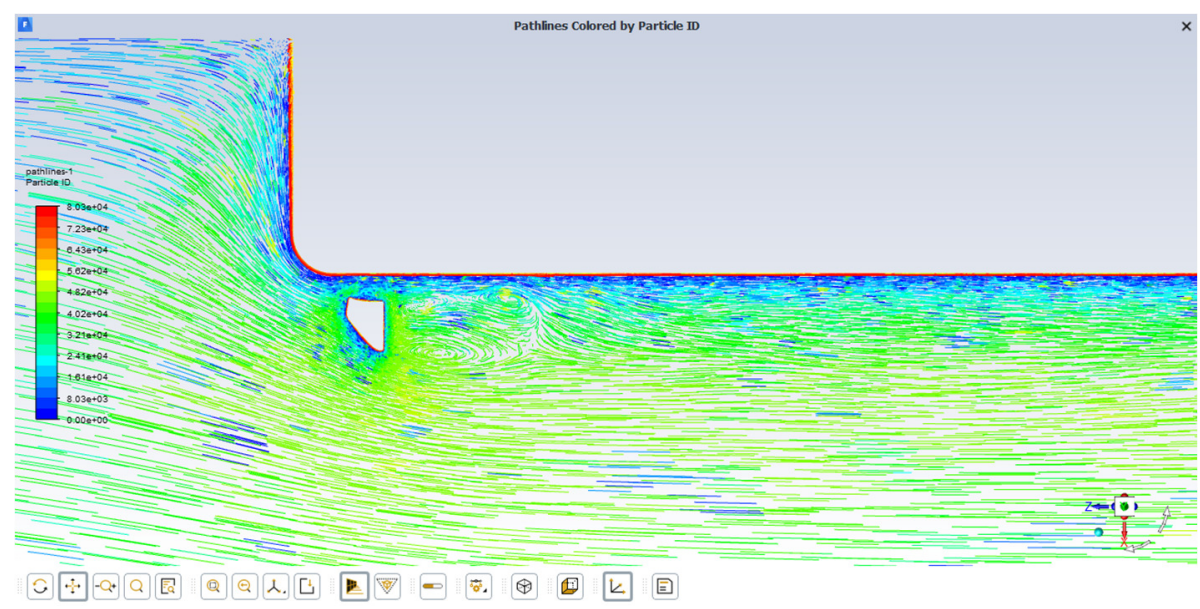

Rysunek 12. Linie przeptywu dla trzeciego lusterka

Tabela 3. Wyniki obliczeń dla trzeciego modelu lusterka

\begin{tabular}{|c|c|}
\hline Współczynnik $\mathrm{C}_{\mathrm{d}}$ & Siła oporów [N] \\
\hline 0,83 & 59,8 \\
\hline
\end{tabular}

Ostatnim modelem jest, zamiana lusterka w inne urządzenie widzenia pośredniego, jest to uchwyt kamery. Zgodnie $\mathrm{z}$ prawem dopuszczalne jest zainstalowanie urządzenia składającego się z kamery oraz monitora, zastępującego klasyczne lusterko. Wymiary tego urządzenia są znacznie mniejsze rysunek 13 , to powoduje znaczne spadki oporów aerodynamicznych, widocznych na rysunku 14. Jednak dopiero w ostatnich latach rozpoczęto wprowadzanie tego typu urządzeń do pojazdów komercyjnych.

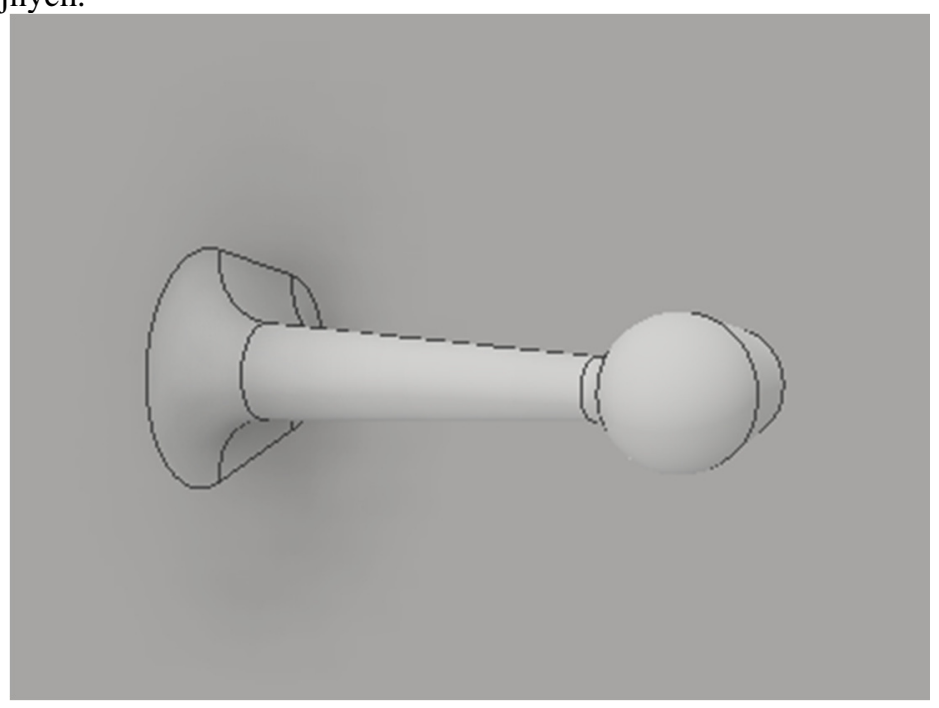

Rysunek 13. Model kamery 


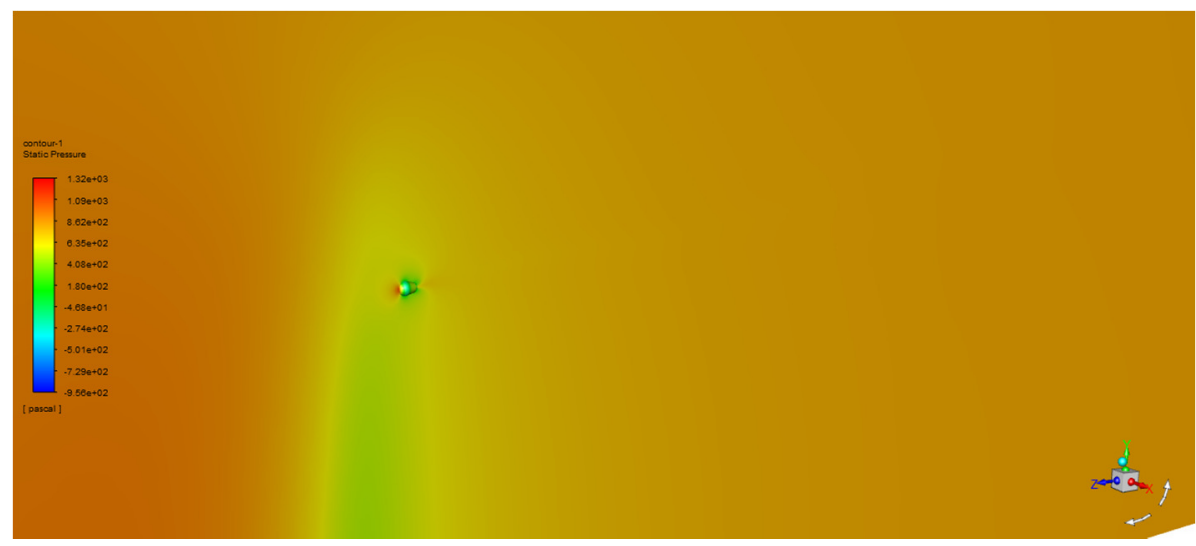

Rysunek 14. Rozktad ciśnień dla kamery

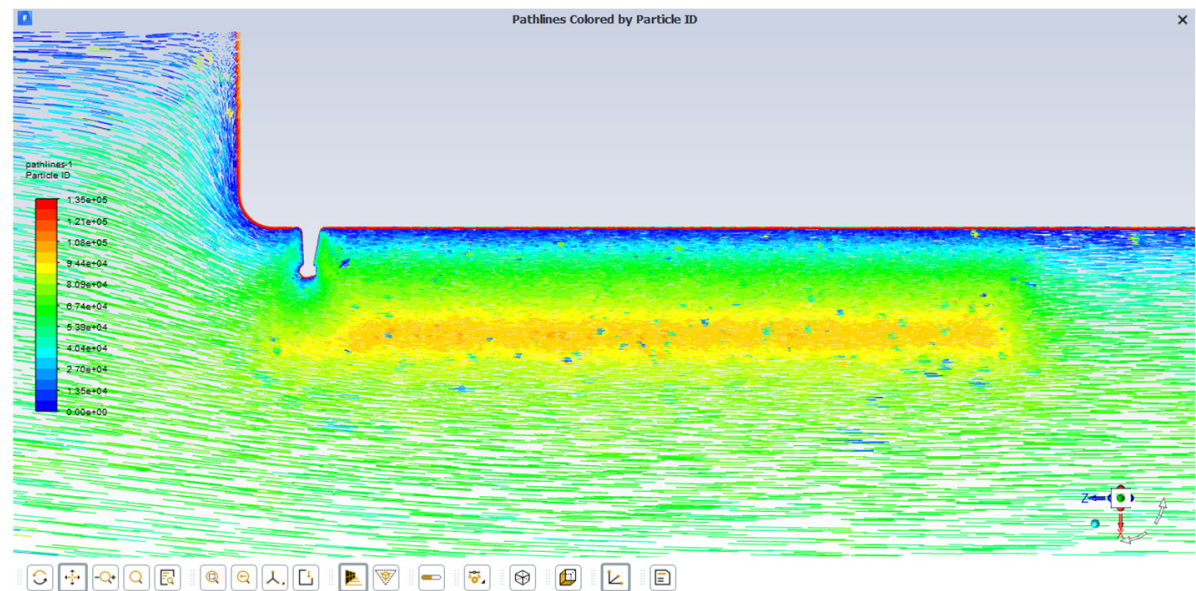

Rysunek 15 . Linie przepływu dla kamery

Tabela 4. Wyniki obliczeń dla kamery

\begin{tabular}{|l|l|}
\hline Współczynnik $\mathrm{C}_{\mathrm{d}}$ & Siła oporów $[\mathrm{N}]$ \\
\hline 0,36 & 4,2 \\
\hline
\end{tabular}

\section{Podsumowanie}

Wyniki optymalizacji przedstawiono w tabeli 5. Wnioski z tabeli pozwalają ocenić iż, kształt lusterka pojazdu ciężarowego ma znaczący wpływ na opory aerodynamiczne wytwarzane przez ten pojazd. Wartości sił oporów spadły z 229,8 [N] do 119,6 [N] w przypadku lusterka oraz do 8,4 [N] w przypadku kamery. Są to znaczne wartości które przedstawiają znaczące zmniejszenie zużycia paliwa przez tego typu pojazd. Suma wszystkich sił działających na pojazd 3193 [N], z czego 2793 [N] czyli 87,47\% to siły wynikające $\mathrm{z}$ oporów aerodynamicznych. Przy założeniu że samochód ciężarowy spala $351 / 100 \mathrm{~km}$ oraz że lusterko pierwszego modelu jest punktem 
odniesienia, obliczyć obliczono przedstawione w tabeli 5 wartości. Dla najbardziej opływowego lusterka uzyskano spadek zużycia paliwa na poziomie 1,2 [1/100km]. Jest to znaczący wynik. Przykładowo pojazd tego typu pokonuje dziennie ok. 700 [km], czyli dzienna oszczędność paliwa wynosi 8,4 [1]. W przypadku kamery spadek zużycia paliwa jest jeszcze większy, wynosi 2,43 [1/100km]. Daje on dzienna oszczędność paliwa na poziomie 17,01 [1].

Tabela 5. Wyniki przeprowadzonej analizy

\begin{tabular}{|c|c|c|c|c|}
\hline Model & $\begin{array}{c}\text { Siła oporów } \\
\text { aerodynamicznych } \\
\text { powstałych na } \\
\text { lusterkach po obu } \\
\text { stronach pojazdu [N] }\end{array}$ & $\begin{array}{c}\text { Zmniejszenie } \\
\text { oporów } \\
\text { aerodynamicznych } \\
\text { w [\%] }\end{array}$ & $\begin{array}{c}\text { Zmniejszenie } \\
\text { zużycia } \\
\text { paliwa w [\%] }\end{array}$ & $\begin{array}{c}\text { Zmniejszenie } \\
\text { zużycia } \\
\text { paliwa w [1] } \\
\text { na 100 [km] }\end{array}$ \\
\hline Lusterko 1 & 229,8 & - & - & - \\
\hline Lusterko 2 & 144,2 & 3,1 & 2,7 & 0,94 \\
\hline Lusterko 3 & 119,6 & 4 & 3,4 & 1,2 \\
\hline Kamera & 8,4 & 7,9 & 6,4 & 2,43 \\
\hline
\end{tabular}

\section{LITERATURA}

1. Regulamin nr 46 Europejskiej Komisji Gospodarczej Organizacji Narodów Zjednoczonych (EKG ONZ) - Jednolite wymagania dotyczące homologacji urządzeń widzenia pośredniego oraz homologacji pojazdów silnikowych w odniesieniu do instalacji tych urządzeń.

2. ZAWIŚLAK M.: Metoda projektowania i modernizacji maszyn oraz układów przepływowych $\mathrm{z}$ zastosowaniem numerycznej mechaniki płynów, Wydawnictwo Politechniki Poznańskiej, 2017. 